\title{
Effects of Trichoderma longibrachiatum (NGJ167) and compost on early growth of Bougainvillea spectabilis
}

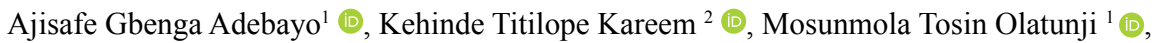

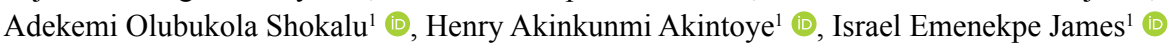 \\ ${ }^{1}$ National Horticultural Research Institute, Ibadan, Nigeria \\ ${ }^{2}$ Agricultural Research and Training, Obafemi Awolowo University, Moor Plantation, Ibadan, Nigeria
}

\begin{abstract}
Bougainvillea spectabilis is an ornamental plant grown in both temperate and tropical zones. They are primarily propagated by stem cuttings; however, difficulty in growth at early stages occurs routinely, causing barrier for its mass propagation. This study was conducted to study the effects of integrating compost with Trichoderma longibrachiatum (NGJ167), in improving the early growth of Bougainvillea spectabilis. Trichoderma longibrachiatum (NGJ167) used for this purpose was obtained from the Bioscience Center, International Institute of Tropical Agriculture (IITA), Ibadan. One hundred and twenty (120) pots were filled with $5 \mathrm{~kg}$ top soil each from an alfisol. Treatments included: Top soil as Control (C), Top soil inoculated with T. longibrachiatum (T), Top soil + compost at 5, 10 and $15 \mathrm{tha}^{-1}$ as $\mathrm{C} 1, \mathrm{C} 2, \mathrm{C} 3$ respectively, Top soil inoculated with $\mathrm{T}$. longibrachiatum + compost at 5, 10 and $15 \mathrm{t}$ $\mathrm{ha}^{-1}$ as C1T, C2T, C3T respectively. The eight treatments were arranged in a completely randomized design (CRD) and replicated three times. Results indicated that integrated use of compost with Trichoderma significantly $(p<0.05)$ had higher growth values than the control. Higher plant height, stem diameter, number of branches and number of leaves, were recorded with the use of compost at $10 \mathrm{t} \mathrm{ha}^{-1}$ compared to control. Compost with Trichoderma gave higher shoot dry weight compared to treatments of compost alone. In conclusion, use of compost alone or inoculated with Trichoderma had significant effect on early growth and development of Bougainvillea spectabilis.
\end{abstract}

Keywords: Bougainvillea, enzymes, growth.

\section{Resumo}

Efeitos de Trichoderma longibrachiatum (NGJ167) e composto no crescimento inicial de Bougainvillea spectabilis Bougainvillea spectabilis é uma planta ornamental cultivada em zonas temperadas e tropicais. Elas são propagadas principalmente por estacas de caule; no entanto, a dificuldade de crescimento nos estágios iniciais ocorre rotineiramente, causando barreira para sua propagação em massa. Este estudo foi realizado para estudar os efeitos da integração de composto com Trichoderma longibrachiatum (NGJ167), na melhora do crescimento inicial de Bougainvillea spectabilis. O Trichoderma longibrachiatum (NGJ167) utilizado para este fim foi obtido no Bioscience Centre, International Institute of Tropical Agriculture (IITA), Ibadan. Cento e vinte (120) vasos foram cheios com $5 \mathrm{~kg}$ de solo superficial de um alfisol. Os tratamentos incluíram: solo superficial como controle (C), solo superficial inoculado com T. longibrachiatum (T), solo superficial + composto em 5, 10 e $15 \mathrm{t} \mathrm{ha}^{-1} \mathrm{como} \mathrm{C} 1$, C2, C3 respectivamente, solo superficial inoculado com T. longibrachiatum + composto a 5, 10 e 15 t ha-1 como C1T, C2T, C3T respectivamente. Os oito tratamentos foram arranjados em delineamento inteiramente casualizado (CRD) e repetidos três vezes. Os resultados indicaram que o uso integrado de composto com Trichoderma significativamente $(p<0,05)$ teve maiores valores de crescimento do que o controle. Maior altura da planta, diâmetro do caule, número de ramos e número de folhas, foram registrados com o uso de composto a $10 \mathrm{t} \mathrm{ha}^{-1}$ em relação ao controle. Composto com Trichoderma aumentou o peso seco da parte aérea em comparação com tratamentos de composto sozinho. Em conclusão, o uso de composto sozinho ou inoculado com Trichoderma teve efeito significativo no crescimento e desenvolvimento inicial de Bougainvillea spectabilis.

Palavras-chave: Bougainvillea, crescimento, enzimas.

*Corresponding author: Corresponding author: ajisafeag@yahoo.com 


\section{Introduction}

Bougainvillea spectabilis of the genus Bougainvillea is a perennial shrub climber and an ornamental evergreen flower that grows in subtropical climate. They have thorns that develop from the leaf base, their leaves are oval shaped, and flowers are small in size ranging from white, purple, pink, red and purplish colors with different varieties (Kobayashi et al., 2007). Bougainvillea is used as house plant, in the landscape. Its drought and salt tolerance characteristics make possible for year-round cultivation and a natural choice for colour in coastal regions (Gilman, 1999). It can be grown and pruned to standard in containers, along fenced lines, on walls, on hanging baskets, as a hedge or an accent plant (Hamilton and Midcap, 2003). Growing bougainvillea is particularly challenging. Gardeners mostly propagate bougainvillea from cuttings, by inserting a sizeable length into nutrient rich soil that is kept moist, however, it can also be propagated by seeds (Singh et al., 2011). The difficulties experienced in its propagation, especially the variegated types, make its seedlings more expensive in Nigeria, thus the need for propagation studies with growth media and manure that can promote its early growth and development.

Compost is an organic fertilizer made from plant and animal wastes, which have been decomposed by existing microorganisms, into a soil-like material in the presence of water and air (Kiyanori, 1990; Yinda and Adeoye, 1995). Composting is the process of transforming biodegradable organic materials into stable usable products, suitable for soil amendment without offensive odors or weed seeds and pathogenic organisms (Kiyanori 1990; Akanbi, 2007). Addition of compost improves soil physical, chemical and biological activities, as well as increase crop yields and nutritional values. It also maximizes use of available farm organic wastes and minimizes use of costly inorganic fertilizers and agrochemicals (Manral and Saxena, 2003; Ghosh et al., 2004).

The genus Trichoderma is a plant growth-promoting microbe which belongs to a large number of rhizosphere filamentous fungal strains found in a wide variety of ecosystems (Harman et al., 2004). They are one of the most versatile opportunistic plant symbionts isolated from forest or agricultural soils and can be easily cultured in vitro (Brotman et al., 2013). They present a typical green sporulation, while some species produce a characteristic sweet or 'coconut' odor due to a biologically active volatile compound (6-pentyl- $\alpha$-pyrone) (Brotman et al., 2010). The interaction of Trichoderma strains with plant may promote plant growth and development, improve crop yield, increase nutrient availability and enhance disease resistance (Harman et al., 2004). In addition, some species of Trichoderma are able to colonize root surfaces, interact with the plant, and exchange compounds that can cause substantial changes in plant metabolism (Yedidia et al., 2001). There is little or no information on the use of plant growth-promoting fungi for incorporation into growth media used for the propagation of bougainvillea. The aim of this study is to investigate the effects of compost and
Trichoderma longibrachiatum (NGJ167) in improving early growth and development of Bougainvillea species.

\section{Materials and Methods}

\section{Experimental site and planting procedure}

The study was carried out at Floriculture Programme screen house, National Horticultural Research Institute (NIHORT), Ibadan, Nigeria $\left(7^{0} 25^{\prime} \mathrm{N}-3^{0} 52^{`} \mathrm{E}\right)$. The experiment consisted of eight treatments which include the following: Top soil as control (C), Top soil inoculated with plant growth promoting fungus (T. longibrachiatum NGJ167) (T), Compost at 5, 10 and 15 tons ha ${ }^{-1}$ denoted as $\mathrm{C} 1, \mathrm{C} 2, \mathrm{C} 3$ respectively, and Top soil inoculated with T. longibrachiatum NGJ167 with compost at 5, 10 and 15 tons ha $^{-1}$ denoted as $\mathrm{C} 1 \mathrm{~T}, \mathrm{C} 2 \mathrm{~T}, \mathrm{C} 3 \mathrm{~T}$ respectively. The experiment was arranged in a complete randomized design (CRD) with three replications. Polyethylene planting bags containing the different treatments were arranged in plots and each plot comprised of five planting bags resulting in forty (40) planting bags per replicate. The total plant population was 120 . One week after the application of the treatments, softwood stem cuttings of bougainvillea (10 $\mathrm{cm})$ with 4 to 6 nodes were inserted into each polyethylene bag $(10 \times 13 \mathrm{~cm})$ containing $5 \mathrm{~kg}$ topsoil each. The soil was watered to field capacity and placed in a moist propagation chamber. The moist propagation chamber was locally constructed with wooden frame completely covered with plain polythene sheets. The experiment was repeated and the data for the two trials were averaged and analyzed.

\section{Inoculum preparation}

The inoculum was prepared by culturing $T$. longibrachiatum NGJ167 in Potato dextrose agar (PDA) for 5 days at $25 \pm 1{ }^{\circ} \mathrm{C}$. Conidial suspension of $T$. longibrachiatum was harvested by flooding the culture plate with sterile distilled water and gently scraped with spatula. Thereafter, the conidia were filtered through three layers of cheese-cloth. The cells were re-suspended in sterile distilled water and adjusted to a final concentration of $10^{8}$ micro conidia $\mathrm{ml}^{-1}$ using haemocytometer. A 100 $\mathrm{ml}$ inoculum of cells was mixed with $5 \mathrm{~kg}$ topsoil before introducing the stem cuttings.

\section{Compost preparation:}

Compost preparation was by mixing dried cassava peel and cured poultry manure from battery cage system in ratio 3:1 dried basis, respectively. Compost materials were sorted out by removal of non-composting materials such as stones, hard cassava stocks etc. Bin method of composting was adopted using 300 litres black bin aerated with bamboo poles at the top, middle and the base. Initial temperatures of the compost at ambient temperature was taken, and thereafter recorded daily in the first three days and later taken weekly until a constant was achieved. Compost was turned fortnightly until maturity at twelve weeks after composting. Samples of matured and dried compost was analyzed using standard procedures. 
Determination of enzymes and plant growth hormones

Matured compost and T. longibrachiatum NGJ167 were analyzed for metabolizing enzymes and plant growth hormones following standard procedures (AMC-RSC, 1990).

\section{Enzyme assay}

Approximately $1.0 \mathrm{~g}$ of compost was weighed into a conical flask and $10.0 \mathrm{ml}$ of $10 \mathrm{mM}$ acetate buffer ( $\mathrm{pH} 5.0$ ) containing $5 \mathrm{mM}$ DDT and $90.0 \mathrm{mM} \mathrm{NaCl}$ were added. The mixture was maintained at $4{ }^{\circ} \mathrm{C}$ for $12 \mathrm{~h}$. Later, it was centrifuged at $20{ }^{\circ} \mathrm{C}(10,000 \mathrm{x} \mathrm{g})$ for $20 \mathrm{~min}$ and filtered. The filtrate was used for further studies as a crude enzyme extract. However, spore suspension of T. longibrachiatum NGJ167 was obtained by culturing it in Potato dextrose broth for 5 days and $1 \mathrm{ml}$ of the spore suspension was measured into a conical flask and the reagents above were also added for further enzyme studies explained below.

Peroxidase activity was measured by adding $1.0 \mathrm{ml}$ of $0.1 \mathrm{M}$ phenylenediamine, $1.0 \mathrm{ml}$ of $3 \% \mathrm{H}_{2} \mathrm{O}_{2}$ and $3.0 \mathrm{ml}$ of $0.1 \mathrm{M}$ sodium acetate buffer ( $\mathrm{pH}$ 6.5) into the conical flask. The mixture was vigorously mixed and then transferred into a cuvette. The change in absorbance was read after $60 \mathrm{~s}$ intervals at $495 \mathrm{~nm}$. $\beta$-1,3-glucanase activity was determined by adding $4.0 \mathrm{ml}$ of $50 \mathrm{mM}$ sodium acetate buffer ( $\mathrm{pH} 4.5)$ and $1.0 \mathrm{mM}$ guaiacol into the conical flask and incubating at $30{ }^{\circ} \mathrm{C}$. The change in absorbance due to oxidation of guaiacol in the mixture was read at $465 \mathrm{~nm}$. Hydrolase was determined by mixing to a final concentration, $2.0 \mathrm{mM}$ PNP $\alpha-\mathrm{G}$ (dissolved in $10 \mathrm{mM}$ sodium acetate buffer, $\mathrm{pH} 5.0$ containing $1.0 \mathrm{mM}$ EDTA) and an appropriate amount of enzyme solution. The total reaction mixture was $3.0 \mathrm{ml}$ and was incubated at $40{ }^{\circ} \mathrm{C}$ for $30 \mathrm{~min}$. The reaction was stopped by adding $5.0 \mathrm{ml}$ of $0.1 \mathrm{M}$ sodium carbonate and the absorbance was read at $400 \mathrm{~nm}$.

Chitinase activity was determined by using colloidal chitin as substrate. About $1.0 \mathrm{ml}$ enzyme solution was added to $1.0 \mathrm{ml}$ substrate solution containing $0.5 \%$ suspension of colloidal chitin prepared in $50 \mathrm{mM}$ sodium phosphate buffer ( $\mathrm{pH} \mathrm{6.0)}$ and incubated at $50^{\circ} \mathrm{C}$ for $1 \mathrm{~h}$. The reaction was stopped by adding $3 \mathrm{ml}$ of dinitrosalicylate (DNS) reagent and heated in a boiling water bath for $15 \mathrm{mins}$. The absorbance of reaction mixture was measured at $660 \mathrm{~nm}$.

\section{Hormone assay}

Spore suspension of $T$. longibrachiatum NGJ167 was obtained by culturing it in Potato dextrose broth for 5 days. About $1 \mathrm{ml}$ of the spore suspension was measured into a conical flask and $0.2 \mathrm{ml}$ of $\mathrm{MgCO}_{3}$ solution added. The mixture was placed in a blender and it was covered with 2 to $3 \mathrm{ml}$ of aqueous acetone solution and macerated. It was transferred into a centrifuge tube and the volume brought up to $5 \mathrm{ml}$ with acetone solution. This was steeped overnight at $4{ }^{\circ} \mathrm{C}$ in the dark. Extract was clarified by centrifuging for 20 mins at 5,000 rpm. Clarified extract was decanted into a clear $15 \mathrm{ml}$ centrifuge tube and the total volume of extract measured. The extract was transferred into the cuvette and the optical density (Spectronic 21D) determined at absorbance of $663 \mathrm{~nm}$ and $750 \mathrm{~nm}$ before and after addition of $0.02 \mathrm{ml}$ of $1 \mathrm{~N} \mathrm{HCl} \mathrm{ml}^{-1}$. Standards were prepared using $0.5 \mathrm{ppm}, 1.0 \mathrm{ppm}, 1.5 \mathrm{ppm}, 2.0 \mathrm{ppm}$ from $10 \mathrm{ppm}$ stock standards of auxin, cytokinin, gibberellins and ethylene separately according to the method adopted by AMC-RSC (1990). The concentration of each hormone was calculated based on the absorbance values and the slope obtained from the standard curve. Approximately $1.0 \mathrm{~g}$ of compost was weighed into a conical flask and similar treatment given to T. longibrachiatum was given and hormone concentration determined as above.

Hormone $(\mathrm{mg} / 100 \mathrm{~g})=$ Absorbance at $750-$ Absorbance at $663+\mathrm{V}_{1}+100 \mathrm{X}$ slope

$\mathrm{V}_{2}$

Where $\mathrm{V}_{1}=$ Volume of extract, $\mathrm{V}_{2}=$ Volume of sample

\section{Determination of plant growth parameters}

Plant height was determined by using a meter rule to measure the height of the plants from the base to the apex in $\mathrm{cm}$ while stem diameter was measured with a vernier caliper. Number of leaves was determined by counting all the leaves found on the plant and number of branches was determined by counting the branches that are found on the plant. Dry weights of leaves, stems and roots were evaluated by uprooting the plant and washing off the soil adhering to the roots. The leaves were detached from the whole plant and the root was cut off from the stem. All the parts were air-dried until constant weights were obtained.

\section{Data Collection and Analysis}

Data collection started at two weeks after stem cuttings have been inserted into the pots and was carried out every fortnight (two weeks' interval) for eight weeks, resulting in four evaluations. Data assessed includes plant height, stem diameter, number of leaves, number of branches, and dry weight of leaves, stems and roots. Data were subjected to analysis of variance and means were compared using the Least Significant Difference (LSD) at $\mathrm{p} \leq 0.05$ (SAS, 1994).

\section{Results and Discussion}

\section{Analysis of the compost and Trichoderma longibrachiatum}

Compost was slightly alkaline (Table 1) and contained higher amount of nitrogen $(\mathrm{N})$, Phosphorus (P), and potassium $(\mathrm{K})$ than cassava peel. Trace elements such Iron $(\mathrm{Fe})$, Zinc $(\mathrm{Zn})$, Copper $(\mathrm{Cu})$ and Manganese $(\mathrm{Mn})$ contents were higher in the matured compost when compared with cassava peel. Also, $\mathrm{Fe}$ and $\mathrm{N}$ content of compost was higher than that of poultry manure but the Mn content was lower in the compost. Edward et al. (1992) and Ashutosh et al. (2006) had earlier observed that composting provides incentives for recovering locked nutrients in wastes and increase the manure values of the materials. 
Table 1. Chemical properties of poultry manure, cassava peel and matured compost

\begin{tabular}{|c|c|c|c|}
\hline Properties & $\begin{array}{c}\text { Poultry } \\
\text { manure }\end{array}$ & Cassava peel & $\begin{array}{c}\text { Matured } \\
\text { compost }\end{array}$ \\
\hline $\mathrm{pH}\left[\mathrm{H}_{2} \mathrm{O}\right]^{*}$ & 8.4 & 6.0 & 8.2 \\
\hline Org. C (\%) & 18.30 & 20.57 & 64.86 \\
\hline Total N (mg g-1) & 4.6 & 4.6 & 5.0 \\
\hline $\mathrm{P}\left(\mathrm{mg} \mathrm{g}^{-1}\right)$ & 39 & 0.5 & 15.9 \\
\hline $\mathrm{K}\left(\mathrm{mg} \mathrm{g}^{-1}\right)$ & 8.8 & 9.7 & 7.6 \\
\hline $\mathrm{Na}\left(\mathrm{mg} \mathrm{g}^{-1}\right)$ & 2.5 & 0.3 & 1.7 \\
\hline $\mathrm{Fe}\left(\mathrm{mg} \mathrm{g}^{-1}\right)$ & 7.0 & 0.7 & 12.0 \\
\hline $\mathrm{Zn}\left(\mathrm{mg} \mathrm{kg}^{-1}\right)$ & 385 & 14 & 154 \\
\hline $\mathrm{Cu}\left(\mathrm{mg} \mathrm{kg}^{-1}\right)$ & 59 & 10 & 31 \\
\hline $\mathrm{Mn}\left(\mathrm{mg} \mathrm{kg}^{-1}\right)$ & 526 & 80 & 372 \\
\hline * & $\mathrm{Aqueous} \mathrm{suspension} \mathrm{of} \mathrm{matured} \mathrm{compost.}$ & \\
\hline
\end{tabular}

Effects of compost and T. longibrachiatum on growth and dry weight of Bougainvillea

Treatment has significant effect $(p \leq 0.05)$ on plant height, number of leaves, and partitioning of dry matter (Table 2).

There was a significant $(p \leq 0.05)$ difference in plant growth with addition of treatments. Bougainvillea cuttings treated with compost applied at $10 \mathrm{t} \mathrm{ha}^{-1}$ (C2) had higher plant height $(61.12 \mathrm{~cm})$, stem diameter $(2.95$ $\mathrm{cm})$, number of branches (8.17) and number of leaves (157.55). This was followed in descending order by C2T having mean plant height of $59.25 \mathrm{~cm}$ and stem diameter of $0.74 \mathrm{~cm}$. Dry weight also varied according to treatments, C2 had higher leaf dry weight, followed by treatment with $T$. longibrachiatum alone (T). All the treatments with compost and $T$. longibrachiatum resulted in higher growth and dry matter content than the control (Table 3).

Table 2: ANOVA table showing the effects of T. longibrachiatum (NGJ167) and compost on early growth and dry matter yield of Bougainvillea spectabilis

\begin{tabular}{|c|c|c|c|c|c|c|c|c|}
\hline $\begin{array}{c}\text { Source of } \\
\text { variation }\end{array}$ & df & $\begin{array}{c}\text { Plant } \\
\text { height } \mathbf{( c m )}\end{array}$ & $\begin{array}{c}\text { Stem diameter } \\
\mathbf{( c m )}\end{array}$ & $\begin{array}{c}\text { Number of } \\
\text { branches }\end{array}$ & $\begin{array}{c}\text { Number of } \\
\text { leaves }\end{array}$ & \multicolumn{2}{|c|}{ Dry weight (g) } \\
\hline Treatment & 7 & $1619.50^{*}$ & $2.07^{\text {ns }}$ & $9.54^{*}$ & $10585.25^{*}$ & $37.65^{*}$ & $215.88^{\text {ns }}$ & $280.48^{*}$ \\
\hline Error & 16 & 406.28 & 1.21 & 5.44 & 994.55 & 21.65 & 115.54 & 150.21 \\
\hline Corrected Total & 23 & & & & & & \\
\hline
\end{tabular}

$\mathrm{df}=$ degree of freedom, $*$ = significant at $1 \%$ level of probability, ns $=$ not significant

Table 3: Effects of T. longibrachiatum (NGJ167) and compost on early growth and dry matter yield of Bougainvillea spetabilis.

\begin{tabular}{|c|c|c|c|c|c|c|c|}
\hline Treatment & $\begin{array}{c}\text { Plant } \\
\text { height } \mathbf{( c m )}\end{array}$ & $\begin{array}{c}\text { Stem } \\
\text { diameter } \mathbf{( c m )}\end{array}$ & $\begin{array}{c}\text { Number } \\
\text { of branches }\end{array}$ & $\begin{array}{c}\text { Number of } \\
\text { Leaves }\end{array}$ & $\begin{array}{c}\text { DWL } \\
\mathbf{( g )}\end{array}$ & $\begin{array}{c}\text { DWS } \\
\mathbf{( g )}\end{array}$ \\
\hline C & 30.42 & 0.44 & 3.41 & 10.72 & 11.72 & 0.21 & 0.003 \\
\hline T & 55.39 & 0.64 & 4.5 & 143.67 & 144.67 & 0.1 & 0.002 \\
\hline C1 & 35.36 & 1.26 & 3.5 & 92.42 & 93.42 & 9.61 & 10.34 \\
\hline C2 & 61.12 & 2.95 & 8.17 & 157.55 & 158.55 & 5.69 & 4.75 \\
\hline C3 & 11.33 & 0.7 & 3.73 & 11.0 & 12.0 & 9.63 & 6.38 \\
\hline C1T & 30.42 & 0.55 & 2.33 & 10.72 & 11.72 & 18.23 & 7.69 \\
\hline C2T & 59.25 & 0.74 & 4.33 & 98.33 & 99.33 & 18.44 & 4.76 \\
\hline C3T & 55.22 & 0.62 & 3.5 & 96.5 & 97.5 & 22.43 & 5.25 \\
\hline LSD & 34.89 & 1.91 & 4.03 & 54.59 & 55.59 & 18.61 & 8.05 \\
\hline
\end{tabular}

C: Control, T: Trichoderma, C1: Compost applied at $5 \mathrm{tha}-1, \mathrm{C} 2$ : compost applied at $10 \mathrm{tha}-1, \mathrm{C} 3$ : Compost applied at $15 \mathrm{tha}-1$,

C1T: Compost applied at 5 tha- $1+$ Trichoderma,

C2T: Compost applied at 10 tha-1 + Trichoderma, C3T: Compost applied at 15 tha-1 + Trichoderma.

DWR: Dry weight of root, DWS: Dry weight of shoot, DWL: Dry weight of leaves, 
This could be attributed to the higher concentration of growth enhancing enzymes present in the compost (Figures 1 and 2). This study shows that Bougainvillea growth can be enhanced by use of compost and compost integrated with $T$. longibrachiatum. This is supported by a number of previous observations where Trichoderma spp. was shown to colonize plant roots, establish symbiotic relationships with a wide range of host plants, and promote growth and development (Shoresh et al., 2010; Harman, 2011).

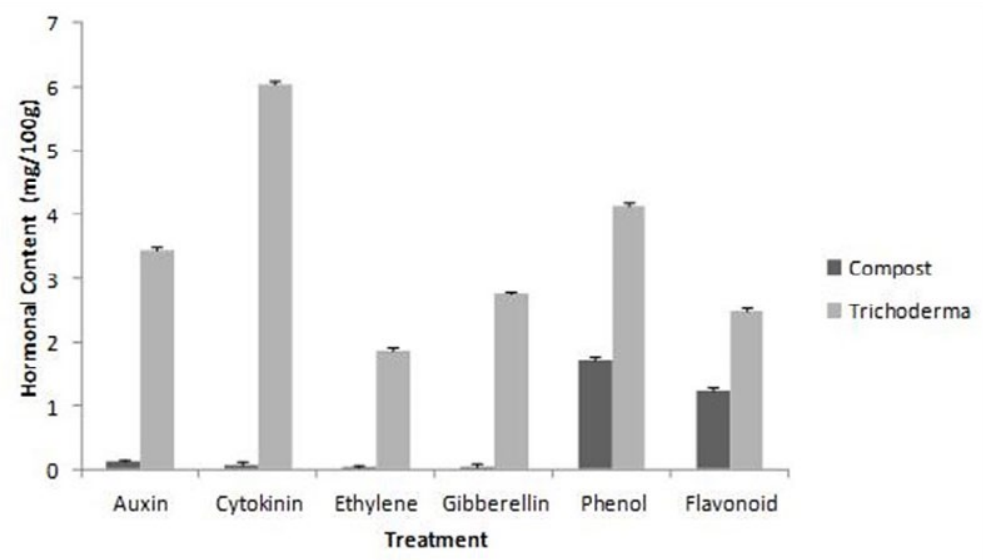

Figure 1. Hormonal content of compost and Trichoderma longibrachiatum (NGJ167).

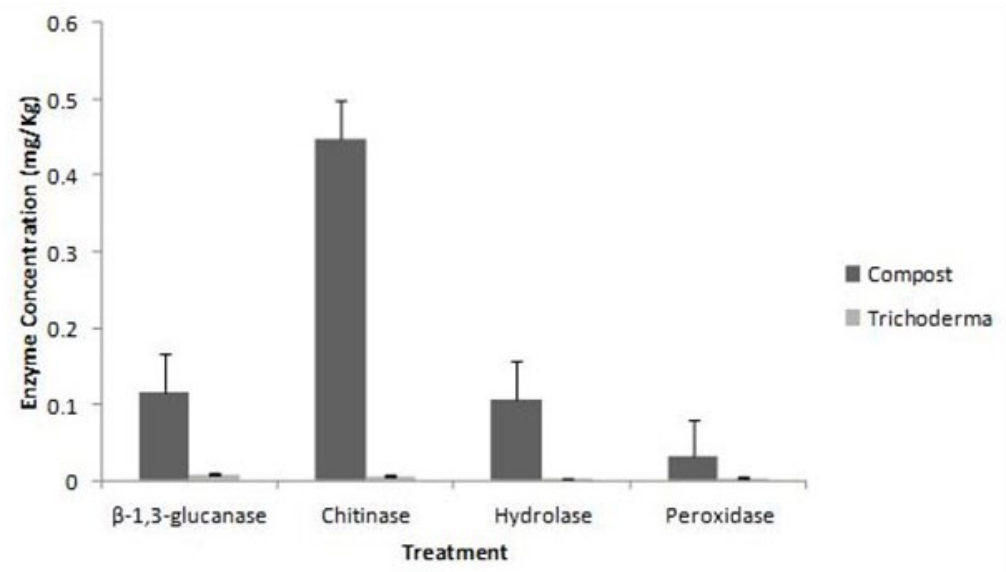

Figure 2. Enzyme Concentration in compost and Trichoderma longibrachiatum (NGJ167).

\section{Hormonal and Enzymes concentration of $T$ longibrachiatum and Compost}

Auxins were first found to stimulate root growth in the 1930s (Thimann and Went, 1934). They demonstrated that the most reliable plant growth regulators in stimulating root production in cuttings were indole-3-butyric acid (IBA) and $\alpha$-naphthaleneacetic acid (NAA). Plant growth regulator, which acts on cell division and elongation, has been used to stimulate root formation in cuttings of herbaceous and woody plants (Hartmann et al., 2002). Sevik and Guney (2013) reported that even though the auxin group hormones (IAA, IBA, and NAA) may not have an apparent effect on rooting percentage, these hormones were detected to affect the morphological characteristics of the newly generated plants, especially root generation. $\mathrm{GA}_{3}$ application had a considerable effect on stem height. The concentrations of hormones in T. longibrachiatum were significantly ( $p \leq$ 0.05 ) higher than in compost. Flavonoid had the highest value of $1.274 \mathrm{mg} / 100 \mathrm{~g}$ in the compost while the values of ethylene, gibberellin and phenol were not significantly different in the compost. The concentration of cytokinin $(6.055 \mathrm{mg} / 100 \mathrm{~g})$ in $T$. longibrachiatum was significantly higher followed by phenol $(4.46 \mathrm{mg} / 100 \mathrm{~g})$ and then auxin $(3.425 \mathrm{mg} / 100 \mathrm{~g})$.

This finding is in line with our study, revealing the significant $(p \leq 0.05)$ difference in the stem growth with T. longibrachiatum compared with other treatments and control as seen in Figure 1. Production of a number of degradative enzymes, including chitinases, proteases and glucanases is involved in the biocontrol process of plant growth promotion by fungi (Harman et al., 2004). This study showed that higher enzymes were present in the compost than T. longibrachiatum. Chitinase was present at a very high concentration in compost $(0.448 \mathrm{mg} / \mathrm{kg})$ followed by $\beta$-1,3-glucanase $(0.116 \mathrm{mg} / \mathrm{kg})$ and hydrolase $(0.106 \mathrm{mg} /$ $\mathrm{kg})$. In $T$. longibrachiatum, $\beta-1,3$-glucanase $(0.009 \mathrm{mg} /$ $\mathrm{kg}$ ) had a significant higher concentration while hydrolase $(0.003 \mathrm{mg} / \mathrm{kg})$ had the least (Figure 2). Trichoderma 
longibrachiatum, being a saprophyte requires a wide array of enzymes to be able to thrive in diverse situations (Azin et al., 2007). Vandana et al. (2014) reported the significant effects of peroxidase, $\beta$-1,3-glucanase and phenol on the growth response of Piper nigrum.

\section{Conclusions}

Compost and Trichoderma longibrachiatum resulted in higher plant growth and dry matter content than the control. Compost application at $10 \mathrm{t} \mathrm{ha}^{-1}$ is recommended for treatment as soil amendment when growing Bougainvillea in pots from cuttings. Also mixing compost with Trichoderma will also be effective in enhancing the growth and development of Bougainvillea species.

\section{References}

AKANBI, W.B.; ADEBAYO, T.A.; TOGUN, O.A.; ADEYEYE, A.S.; OLANIRAN, O.A. The use of compost extract as foliar spray nutrient source and botanical insecticide in Telfairia occidentalis. World Journal of Agricultural Sciences, v.3, n.5, p.642-652, 2007.

Analytical Methods Committee of the Royal Society of Chemistry (AMC-RSC). Official and standardized methods of analysis. 3ed. Cambridge: Royal Society of Chemistry, 1990. 2366p.

ASHUTOSH, S.; RAJA, M.R.; RINA, C. Effects of four different doses or organic manures in the production of Ceriodaphnia cornuta. Bioresource Technology, v.47, p.1036-1040, 2006. DOI: http://doi.org/10.1016/j. biortech.2005.04.044

AZIN, M.; MORAVEJ, R.; ZAREH, D. Self-directing optimization of parameters for extracellular chitinase production by Trichoderma harzianum in batch mode. Process Biochemistry, v.34, n.6-7, p.563-566, 2007. DOI: http://doi.org/10.1016/S0032-9592(98)00128-9

BROTMAN, Y.; KAPUGANTI, J.G.; VITERBO, A. Trichoderma. Current Biology, v.20, p.390-391, 2010.

BROTMAN, Y.L.; LANDAU, U.; CUADROSINOSTROZA A.; TOHGE, T.; FERNIE, A.R.; CHET, I.; VITERBO, A.; WILLMILZER, L. Trichoderma-plant root colonization: escaping early plant defense responses and activation of the anti-oxidant machinery for saline stress tolerance. PLoS Pathogens, v.9, n.3, p.e1003221, 2013. DOI: http://doi.org/10.1371/journal.ppat.1003221

EDWARD, D.R.; DANIEL, T.C. A review of poultry manure. Bioresource Technology. v.41, p.9-23, 1992. DOI: https://doi.org/10.1016/0960-8524(92)90094-E
GHOSH, P.K.; AJAY, K.K.; MANNA, M.C.; MANDAL, K.G.; MISTRA, A.K.; HATI, K.M. Comparative effectiveness of cattle manure, poultry manure, phosphocompost and fertilizer-NPK on three cropping systems in Ventisols of semi-arid tropics. II. Dry matter yield, nodulation, chlorophyll content and enzyme activity. Bioresource Technology, v.95, p.85-93, 2004. DOI: https://doi.org/10.1016/j.biortech.2004.02.012

GILMAN, E.F. Bougainvillea spp. Fact Sheet FPS-70. Gainesville: Cooperative Extension Service, 1999. 3p.

HAMILTON, D.F.; MIDCAP, J.T. Propagation of woody ornamentals by cuttings. Gainsville: Florida Cooperative Extension Service, Institute of Food and Agricultural Sciences, University of Florida, 2003. 14p.

HARMAN, G.E. Multifunctional fungal plant symbionts: new tools to enhance plant growth and productivity. New Phytologist, v.189, n.3, p.647-649, 2011. DOI: http://doi. org/10.1111/j.1469-8137.2010.03614.x

HARMAN, G.E.; HOWELL, C.R.; VITERBO, A.; CHET, I.; LORITO, M. Trichoderma species-opportunistic avirulent plant symbionts. Nature Reviews Microbiology, v.2, p.43-56, 2004.

HARTMANN, H.T.; KESTER, D.E.; DAVIES, F.T.; DAVIES, F.T.; GENEVE, R.L. Plant Propagation: Principles and practices. New Jersey: Prentice Hall, 2002. $662 \mathrm{p}$.

KIYONORI, H. Production of compost from organic waste. In food and fertilizer. Technology Centre Extension Bulletin, n.311, p.1-17, 1990.

KOBAYASHI, K.D.; MCCONNELLL J.; GRIFFIS, J. Bougainvillea: ornamentals and flowers. Honolulu: University of Hawai, 2007. 12p.

MANRAL, H.S.; SAXENA, S.C. Plant growth, yield attributes and grain yield of soybean as affected by the application of inorganic and organic sources of nutrients. Bioresource Technology, v.92, p.110-118, 2003.

SAS Computer program. SAS/STAT User's Guide: Statistical Methods, 6ed., Iowa State University Press, Iowa, US. 1994.

SEVIK, H.; GUNEY, K. Effects of IAA, IBA, NAA and $\mathrm{GA}_{3}$ on rooting and morphological features of Melissa officinalis L. stem cuttings. The Scientific World Journal, v.2013, p.115-120, 2013. 
SHORESH, M.; HARMAN, G.; MASTOURI, F. Induced systemic resistance and plant responses to fungal biocontrol agents. Annual Reviews Phytopathology, v.48, p.21-48, 2010. DOI: https://doi.org/10.1146/annurevphyto-073009-114450

SINGH, K.K.; RAWAT, J.M.; TOMOR, Y.K. Influence of indole butyric acid (IBA) on rooting potential of Torch Glory Bougainvillea glabra during winter seasons. Journal of Horticultural Science and Ornamental Plants, v.3, n.2, p.162-165, 2011.

THIMANN, K.V.; WENT, F.W. On the chemical nature of the root-forming hormone. Proceedings of the Koninklijke Nederlanse Akademie van Wetenschappen te Amsterdam. v.37, p.456-459, 1934.
VANDANA, V.V.; SUSEELA, B.R.; SHAMINA, A. Biochemical defense responses of black pepper (Piper nigrum L.) lines to Phytophthora capsici. Physiological and Molecular Plant Pathology, v.88, p.18-27, 2014. DOI: http://doi.org/10.1016/j.pmpp.2014.06.003

YEDIDIA, I.; SRIVASTVA, A.K.; KAPULNIK, Y.; CHET, I. Effects of Trichoderma harzianum on microelement concentrations and increased growth of cucumber plants. Plant and Soil, v.235, p.235-242, 2001. DOI: http://doi. org/10.1023/A:1011990013955

YINDA, G.S.; ADEOYE, G.O. A comparative study of two composting methods. Ibadan: University of Ibadan, 1994. 